\title{
"The influence of the central warehouse on the functioning of Polish small and medium-sized enterprises operating in group purchasing organizations"
}

\begin{tabular}{|c|c|}
\hline AUTHORS & $\begin{array}{l}\text { Grzegorz Zimon iD https://orcid.org/0000-0002-2040-4438 } \\
\text { R http://www.researcherid.com/rid/V-5509-2018 }\end{array}$ \\
\hline ARTICLE INFO & $\begin{array}{l}\text { Grzegorz Zimon (2020). The influence of the central warehouse on the } \\
\text { functioning of Polish small and medium-sized enterprises operating in group } \\
\text { purchasing organizations. Problems and Perspectives in Management, 18(1), 26- } \\
\text { 32. doi:10.21511/ppm.18(1).2020.03 }\end{array}$ \\
\hline DOI & http://dx.doi.org/10.21511/ppm.18(1).2020.03 \\
\hline RELEASED ON & Friday, 24 January 2020 \\
\hline RECEIVED ON & Sunday, 27 October 2019 \\
\hline ACCEPTED ON & Thursday, 09 January 2020 \\
\hline LICENSE & $\begin{array}{l}(\mathrm{cc}) \mathrm{EY} \\
\text { This work is licensed under a Creative Commons Attribution } 4.0 \text { International } \\
\text { License }\end{array}$ \\
\hline JOURNAL & "Problems and Perspectives in Management" \\
\hline ISSN PRINT & $1727-7051$ \\
\hline ISSN ONLINE & $1810-5467$ \\
\hline PUBLISHER & LLC "Consulting Publishing Company "Business Perspectives" \\
\hline FOUNDER & LLC "Consulting Publishing Company "Business Perspectives" \\
\hline
\end{tabular}

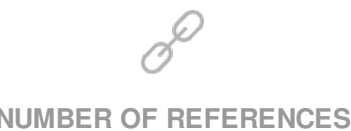

35
NUMBER OF FIGURES

0
NUMBER OF TABLES

4

(C) The author(s) 2022. This publication is an open access article. 


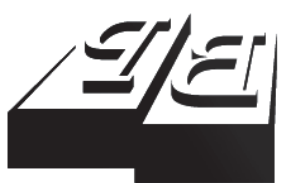

BUSINESS PERSPECTIVES

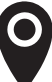

LLC "CPC "Business Perspectives" Hryhorii Skovoroda lane, 10, Sumy, 40022, Ukraine

www.businessperspectives.org

Received on: $27^{\text {th }}$ of October, 2019 Accepted on: $9^{\text {th }}$ of January, 2020

(c) Grzegorz Zimon, 2020

Grzegorz Zimon, Ph.D., Department of Finance, Banking and Accounting, Faculty of Management, Rzeszow University of Technology, Poland.

\section{(c) (i)}

This is an Open Access article, distributed under the terms of the Creative Commons Attribution 4.0 International license, which permits unrestricted re-use, distribution, and reproduction in any medium, provided the original work is properly cited.

\section{THE INFLUENCE}

OF THE CENTRAL WAREHOUSE ON THE FUNCTIONING OF POLISH SMALL AND MEDIUMSIZED ENTERPRISES OPERATING IN GROUP PURCHASING ORGANIZATIONS

\begin{abstract}
Growing competition in the market forces primarily small and medium enterprises (SMEs) to implement certain mechanisms that will allow them to build an advantage over the competition. Most often, SMEs try to work together as part of multi-stakeholder organizations and organize themselves into group purchasing organizations (GPOs) with the central warehouse to improve the financial state of enterprises. The article aims to assess and analyze the impact of the central warehouse on the performance of Polish SMEs operating in group purchasing organizations. The research group comprised of 172 trading enterprises operating in Polish group purchasing organizations. The investigated companies were divided into two groups. In the first group, there were companies operating within GPOs, which have a central warehouse. In the second group, there were companies in which central unit does not have a central warehouse. The analysis and research showed that the central warehouse has a positive impact on financial security of small and medium enterprises operating in group purchasing organizations. The use of central warehouse optimizes the most costly current assets component - inventories. This is confirmed by better results of inventory turnover ratios in days, reduced share of inventories in the structure of current assets, and optimization of financial liquidity ratios.
\end{abstract}

Keywords

JEL Classification
SMEs, inventory, GPOs, financial liquidity

L10, L20, M21, G31

\section{INTRODUCTION}

Small and medium-sized enterprises are looking for tools and methods that will allow them to compete effectively with their competitors. They often mistakenly try to improve their competitiveness by pursuing a cost-cutting policy. Unfortunately, such a strategy leads very often to the reduction in the quality of services or goods sold, which may result in the loss of customers who are slowly beginning to pay attention not only to price, but also to quality. In some areas, the cost-cutting policy does not prove to be effective. An excellent example of the impact of state policy on the cost management of companies is the regulations on minimum wages. The government's announcements of a rapid increase in minimum wages in Poland are a bad signal for small and medium-sized enterprises. Gradual and balanced wages growth is a very good solution to drive the companies. In turn, drastically growing and fixed minimum wages will be a big problem for them. Managers of small and medium-sized enterprises are forced 
to introduce the solutions that will allow them to improve their financial state and effectively compete with their competitors. The simplest solution, which is very often used in Poland and around the world, is cooperation within group purchasing organizations. Recently, group purchasing organizations have appeared on the market which, in order to strengthen their position, are introducing a central warehouse within the structure of their organizations.

The article aims to improve the functioning of group purchasing organization's central unit, as well as of particular members of the organization.

\section{LITERATURE REVIEW}

Joint work and joint purchases were used a long time ago already in ancient Egypt (Wotten, 2003). Group purchasing organizations (GPO) are multi-stakeholder organizations aiming at joint purchasing and the use of economies of scale. Joint work and joint purchasing is aim enable them to obtain low prices in the first place (Kauffman \& Wang, 2002; Zhou, Dan, Ma, \& Zang, 2017; Yang, Cheng, Ding, \& Li, 2017; Nollet \& Beaulieu, 2003, D. Zimon \& G. Zimon, 2019a). Such organizations operate in the public and private sectors, as well as in virtually every industry. Most of the purchasing groups operate in the chemical, food, medical, and construction industries (Schotanus, Telgen, \& de Boer, 2010; Essig, 2000; Marvel \& Yang, 2008; Nollet \& Beaulieu, 2003; Polychronakis \& Syntetos, 2007; Tella \& Virolainen, 2005; Sandberg \& Mena, 2015; Bove \& Arcieri, 2016). In the USA, there are more than 600 health care GPOs, and about 98 percent of hospitals purchase through GPOs $(\mathrm{Hu}, \mathrm{Schwarz}$, \& Uhan, 2012). Additionally, on-line group-buying (OGB) organizations often appear on the market (Che, Peng, \& Hua, 2016).

Many authors confirm that operating in group purchasing organizations brings variety of benefits. Among the most important ones, one can list:

- low prices of purchased goods and services (Faes, Matthyssens, \& Vandenbempt, 2000);

- increased effectiveness of purchasing processes (Nollet, Beaulieu, \& Fabbe-Costes, 2017);

- joining a purchasing group may reduce the prices, reduce the costs of finding, negotiating, and dealing directly with a supplier (Shotanus \& Telgen, 2007);
- $\quad$ sailing transaction cost (Schotanus et al., 2010; Picot et al., 1996; Williamson, 1991);

- reduction of production costs (Vinnig \& Globerman, 1991);

- facilitating the benchmarking (Sarkar, 2001);

- improved cost control (Williamson, 2000);

- reduction of administrative costs (Burns \& Lee, 2008);

- enhancing the bargaining power (Doucette, 1997; Yang et al., 2017).

Operating in groups does not only bring benefits. Sometimes, there are some disadvantages of functioning in group purchasing organizations. Typical disadvantages are set-up costs, coordination costs, losing the flexibility, losing the control (Schotanus, 2005). However, the benefits definitely exceed the disadvantages of functioning within group purchasing organization, thus, their popularity is constantly growing.

There are different types and many classifications of group purchasing organizations on the market. The most significant classification is presented by Schontanus and Telgen (2007) who divide them into five sections. Another important classification concerns the division into industry and multi-industry organizations (G. Zimon \& D. Zimon, 2019b). A similar classification due to different types of activities was already used by Dyer and Singh (1998). This division enables to take advantage of economies of scale to a greater extent, as the effect of joint purchasing is not weakened in industry group purchasing organizations, because all of them operate in the same industry and use the same supplier, the purchasing power is great. It 
allows gaining competitive advantage. Joint work helps to increase the cooperation between all participants, which in the case of group purchasing organizations, is considered as one of the most important factors in ensuring the success of the group (Hoffmann \& Schlosser, 2001; Hagedoorn \& Schakenraad, 1996). In order to improve functioning of particular enterprises operating within a GPO, some modern the central units of GPOs additionally introduce central warehouses. Most often, the central warehouse is introduced just in industry group purchasing organizations.

\section{THEORETICAL FRAMEWORK}

In modern GPOs, a central unit has a central warehouse. Thanks to the warehouse, GPO members gain an additional possibility of replenishing their stocks. The central warehouse has two main functions, it is a source of revenue for the central unit and allows the enterprises to replenish their stocks very quickly. In modern GPOs, the central unit, when executing the transactions with the manufacturer, often orders a given assortment with a certain reserve, which is sent to the central warehouse. Then the reserve is sold to the GPOs members with a higher margin, which is the additional source of revenue for the central unit. In the case of joint purchases and negotiations with manufacturer, the central unit has to meet the agreed purchase limits in order to get favourable discounts. If it is not possible to collect a sufficient number of orders from the organization members, the central unit will fill in the missing amount, which guarantees the achievement of a certain limit. It goes to the central warehouse and is sold later on. The central warehouse is an additional supply channel for the organization members.

In general, in GPOs, most of purchases take place through the central unit. Enterprises report a need for a particular commodity and the central unit is in charge of the organization of orders. In a bigger group purchasing organization, there are several other supply management opportunities:

a) Supplies directly from a manufacturer to an enterprise.
This supply system is possible only in the case of ordering the appropriate volume of assortment determined by the central unit. The central unit determines specific order limits for group members.

b) Supplies with the use of the central unit of the GPO.

The central unit warehouse supply system is a solution for units, which did not join the joint purchase at the time of submitting the offer for a given assortment. Enterprises purchase the goods directly from the central warehouse of the central unit. Higher price of the ordered assortment is a significant disadvantage of this system. An advantage is the low storage costs in the company because the goods are selected from the central warehouse on a Just In Time basis.

c) Combined deliveries.

Combined deliveries are based on Milk-Run. They are used very rarely because an important aspect of group activities is the observance of the principle of regionalization. Only one unit from a GPO can operate in a given area.

d) Deliveries from another company operating within the organization.

This is basically an emergency stock replenishment. Companies may resell goods to each other in mutual transactions. The storage costs are low, but the unit price of the ordered goods is high. Mutual transactions within group purchasing organizations are generally used to facilitate the financial liquidity. A company with low liquidity purchases the goods and obtains a long period of time to repay its liabilities. Seller does not charge interest for late payment, credits the buyer. This type of transaction can be called an "emergency" transaction.

\section{METHODOLOGY}

The study was carried out using the appropriate statistical methods. The research group included 172 trade companies operating in Polish industry group purchasing organizations. The investigated companies were divided into two groups. In the first group, there were companies operating 
within GPOs, which have a central warehouse (50 units). In the second group, there were companies in which central unit does not have a central warehouse (122 units). Using the appropriate financial indicators from the index analysis and appropriate statistical methods, the impact of the central warehouse on the management of the company was assessed. Based on the conducted research, the elements that are significantly affected by the economies of scale appearing in GPOs were identified. The analysis was carried out based on financial data from 2015 to 2017.

\section{RESULTS}

In order to assess the impact of the central warehouse on the management of companies operating in GPOs, two groups of companies were analyzed. In the first group, there were companies operating within GPOs, which have a central warehouse. In the second group, there were companies in which central unit does not have a central warehouse.

The first assessed element was the share of inventories in the structure of current assets. It should be noted that a big share of inventories in the structure of current assets has a negative influence on financial liquidity. Inventories are the least liquid current asset, and the more advantageous situation is when their share is lower in comparison to, e.g., receivables from customers.

Table 1. Average share of inventories in the current assets of the analyzed enterprises

Source: Author's research.

\begin{tabular}{|c|c|c|c|c|c|c|c|c|}
\hline \multirow{2}{*}{$\begin{array}{c}\text { Financial } \\
\text { indicator } \\
\text { The share } \\
\text { of inventories } \\
\text { in current } \\
\text { assets }\end{array}$} & \multicolumn{4}{|c|}{$\begin{array}{l}\text { Group purchasing } \\
\text { organization with a } \\
\text { central warehouse } \\
\text { (50 companies) }\end{array}$} & \multicolumn{4}{|c|}{$\begin{array}{l}\text { Group purchasing } \\
\text { organization without } \\
\text { a central warehouse } \\
\text { (122 companies) }\end{array}$} \\
\hline & $\bar{x}$ & Me & $\min$ & $\max$ & $\bar{x}$ & Me & $\min$ & $\max$ \\
\hline 2015 & 0.50 & 0.50 & 0.26 & 0.57 & 0.60 & 0.63 & 0.36 & 0.73 \\
\hline 2016 & 0.51 & 0.51 & 0.30 & 0.55 & 0.62 & 0.61 & 0.30 & 0.65 \\
\hline 2017 & 0.52 & 0.53 & 0.32 & 0.60 & 0.64 & 0.60 & 0.37 & 0.67 \\
\hline
\end{tabular}

The analysis and results presented in Table 1 clearly indicate that a lower share of inventories in the structure of current assets was achieved by companies that operate within GPOs, which have a central warehouse. The companies use the opportunity to order the goods from the central warehouse. In case of a certain assortment, they try to operate on Just in Time principles.

The effectiveness of inventory management was then evaluated. In the case of a central warehouse and several possibilities to deliver the goods to companies operating in GPOs, their management efficiency is higher than that of companies operating in GPOs that do not use the central warehouse. Detailed results are presented in Table 2 .

Table 2. Average results of inventory turnover in days in the analyzed companies in 2015-2017

Source: Author's research

\begin{tabular}{l|l|l|l|l|l|l|l|l}
\hline $\begin{array}{l}\text { Financial } \\
\text { indicator }\end{array}$ & $\begin{array}{c}\text { Group purchasing } \\
\text { organization with } \\
\text { a central warehouse } \\
\text { (50 companies) }\end{array}$ & $\begin{array}{c}\text { Group purchasing } \\
\text { organization without } \\
\text { a central warehouse } \\
\text { (122 companies) }\end{array}$ \\
\hline $\begin{array}{c}\text { Inventory } \\
\text { turnover } \\
\text { in days }\end{array}$ & $\bar{x}$ & $\mathbf{M e}$ & $\mathbf{m i n}$ & $\mathbf{m a x}$ & $\bar{x}$ & $\mathbf{M e}$ & $\mathbf{m i n}$ & $\mathbf{m a x}$ \\
\hline 2015 & 61.0 & 63.2 & 26.9 & 75.1 & 71.4 & 73.5 & 44.9 & 90.8 \\
\hline 2016 & 64.2 & 65.7 & 20.3 & 87.4 & 76.2 & 72.9 & 40.4 & 103.1 \\
\hline 2017 & 68.8 & 68.9 & 27.4 & 80.3 & 76.7 & 77.9 & 48.2 & 97.8 \\
\hline
\end{tabular}

Faster inventory turnover reduces the inventory management costs and has a positive impact on liquidity management. The results presented in Tables 1 and 2 allow us to state that in the structure of current assets in companies operating in GPOs, which have a central warehouse, receivables from customers have a higher share over the share of inventories. This is very positive information for liquidity management. Table 3 presents the results of the financial liquidity ratio and quick ratio.

Table 3. Average results of financial liquidity in the analyzed companies in 2015-2017

\begin{tabular}{l|c|c|c|c|c|c|c|c} 
& \multicolumn{1}{c}{ Source: Author's research. } \\
\hline $\begin{array}{l}\text { Financial } \\
\text { indicator }\end{array}$ & $\begin{array}{c}\text { Group purchasing } \\
\text { organization with } \\
\text { a central warehouse } \\
\text { (50companies) }\end{array}$ & $\begin{array}{c}\text { Group purchasing } \\
\text { organization without } \\
\text { a central warehouse } \\
\mathbf{( 1 2 2} \text { companies) }\end{array}$ \\
\hline Financial & $\bar{x}$ & $\mathbf{M e}$ & $\mathbf{m i n}$ & $\mathbf{m a x}$ & $\bar{x}$ & $\mathbf{M e}$ & $\mathbf{m i n}$ & $\mathbf{m a x}$ \\
liquidity & 2.4 & 2.2 & 1.3 & 11.0 & 3.1 & 3.0 & 1.2 & 10.8 \\
\hline 2015 & 2.6 & 2.5 & 1.3 & 9.1 & 3.7 & 3.3 & 1.2 & 13.9 \\
\hline 2016 & 3.2 & 3.0 & 1.3 & 8.8 & 3.9 & 3.5 & 1.4 & 15.1 \\
\hline 2017 & & & & & & & & \\
\hline
\end{tabular}

The results presented in Table 3 indicate that there is excess liquidity in the studied companies. 
Excess liquidity guarantees financial security to the companies; however, it also has its cost. Such high ratios should be assessed negatively, unnecessary costs of maintaining current assets are incurred by the companies.

In Table 4, quick ratio is presented. Following the exclusion of inventories from current assets, the analyzed entities still achieved high results. Detailed results are presented in Table 4 .

Table 4. Average results of quick ratio in the analyzed companies in 2015-2017

Source: Author's research.

\begin{tabular}{c|c|c|c|c|c|c|c|c|c}
\hline $\begin{array}{l}\text { Financial } \\
\text { indicator }\end{array}$ & $\begin{array}{c}\text { Group purchasing } \\
\text { organization with } \\
\text { a central warehouse } \\
\text { (50 companies) }\end{array}$ & $\begin{array}{c}\text { Group purchasing } \\
\text { organization without } \\
\text { a central warehouse } \\
\text { (122 companies) }\end{array}$ \\
\hline $\begin{array}{c}\text { Quick } \\
\text { ratio }\end{array}$ & $\bar{x}$ & $\mathbf{M e}$ & $\mathbf{m i n}$ & $\mathbf{m a x}$ & $\bar{x}$ & $\mathbf{M e}$ & $\mathbf{m i n}$ & $\mathbf{m a x}$ \\
\hline 2015 & 1.0 & 0.9 & 0.7 & 2.6 & 0.6 & 0.7 & 0.2 & 2.2 \\
\hline 2016 & 1.1 & 1.0 & 0.9 & 2.5 & 0.9 & 0.9 & 0.3 & 2.5 \\
\hline 2017 & 1.1 & 1.0 & 0.8 & 2.7 & 0.7 & 0.8 & 0.2 & 2.9 \\
\hline
\end{tabular}

When analyzing Table 4, it should be stated that the companies operating in GPOs using the central warehouse obtain more favorable results. In GPOs without a central warehouse, this ratio has clearly lower results. Quick turnover ratio excludes the inventories. This is why in the case of GPOs without a central warehouse, where inventories have a big share in the structure of current assets, liquidity is significantly lower. It can be seen that after excluding the inventories from current assets, these companies may have a liquidity problem.

\section{DISCUSSION}

The introduction of a central warehouse costs the companies operating in group purchasing organizations, which adversely affects their profitability. However, it helps improve inventory management efficiency and financial liquidity results. In general, the literature states that a decrease in profitability often leads to an increase in financial liquidity in SMEs (Ding, Guariglia, \& Knight, 2013; Enqvist, Graham, \& Nikkinen, 2014, Vahid, Elham, Khosroshahi Mohsen, \& Mohammadreza, 2012). It is different in the units analyzed, the costs of maintaining the central warehouse reduce the profitability of enterprises, but most importantly, they will not lead to the appearance of excess liquidity, which is very often a large and unnecessary financial burden on small and medium-sized enterprises.

\section{CONCLUSION}

Based on the analysis, it should be stated that the central warehouse in group purchasing organizations is a beneficial solution. This is proved by the results of inventory turnover ratios in days, financial liquidity, quick ratio, and the share of inventories in current assets. In group purchasing organizations with a central warehouse, the companies achieve lower results in terms of inventory turnover ratios in days. The lower share of inventories in the current assets structure should also be treated as a positive result when compared to companies operating in GPOs where there is no central warehouse. When evaluating the financial liquidity ratios, it should be stated that both groups of companies achieve very high results. Maintaining high liquidity means unnecessary costs. The company's managers should, therefore, eliminate those current assets that are least liquid. The quick ratio achieves significantly better, safer results in the group of companies operating in the GPOs in which the central warehouse operates. In the case of the second group of companies, these ratios are at a dangerously low level, even though the current liquidity ratios were very high before. This result shows how much financial security is affected by inventories.

Summarizing the functioning of the central warehouse, it should be positively assessed from the viewpoint of financial security of small and medium-sized enterprises operating in group purchasing organizations. In the future, however, it would be worthwhile to extend the study to include profitability indicators in order to determine whether functioning in group purchasing organizations with a central warehouse has a significant impact on the profitability of companies. 


\section{REFERENCES}

1. Blair, R. D., \& Durrance, C. P. (2014). Group purchasing organizations, monopsony, and antitrust policy. Managerial Decision Economics, 35(7), 433443. https://doi.org/10.1002/ mde. 2633

2. Bove, E., \& Arcieri, E. (2016). Motivational, Economic and Social Analysis of an Ethical Purchasing Group Active in Potenza in the Fruit \& Vegetable Sector. Agriculture and Agricultural Science Procedia, 8, 803-806. https://doi.org/10.1016/j. aaspro.2016.02.073

3. Burns, L. R., \& Lee, J. A. (2008). Hospital purchasing alliances: Utilization, services, and performance. Health Care Management Review, 33(3), 203-215. Retrieved from https://www.ncbi.nlm.nih.gov/ pubmed/18580300

4. Che, T., Peng, Z., \& Hua, Z. (2016). Characteristics of online group-buying website and consumers intention to revisit: the moderating effects of visit channel. Electronic Commerce Research, 16(2), 171-188. https://doi. org/10.1007/s10660-016-9214-y

5. Ding, S., Guariglia, A., \& Knight, J. (2013). Investment and financing constraints in China: does working capital management make a difference? Journal of Banking and Finance, 37(5), 14901507. https://doi.org/10.1016/j. jbankfin.2012.03.025

6. Dyer, J. H., \& Singh, H. (1998). The relational view: cooperative strategy and sources of interorganizational competitive advantage. Academy of Management Review, 23(4), 660-679. https://doi. org/10.2307/259056

7. Enqvist, J., Graham, M., \& Nikkinen, J. (2014). The impact of working capital management on firm profitability in different business cycles: evidence from Finland. Research in International Business Finance, 32, 36-49. https://doi.org/10.1016/j.ribaf.2014.03.005
8. Essig, M. (2000). Purchasing consortia as symbiotic relationships: developing the concept of "consortium sourcing". European Journal of Purchasing \& Supply Management, 6(1), 13-22. https://doi.org/10.1016/S09697012(99)00031-3

9. Faes, W., Matthyssens, P., \& Vandenbempt, K. (2000). The pursuit of global purchasing synergy. Industrial Marketing Management, 29(6), 539-553. https://doi.org/10.1016/S00198501(00)00127-9

10. Hagedoorn, J., \& Schakenraad, J. (1994). The effect of strategic technology alliances on company performance. Strategic Management Journal, 15(4), 291309. Retrieved from https://www. jstor.org/stable/2486887?seq=1

11. Hoffmann, W., \& Schlosser, R. (2001). Success factors of strategic alliances in small and mediumsized enterprises, an empirical study. Long Range Planning, 34(3), 357-381. https://doi.org/10.1016/ S0024-6301(01)00041-3

12. Hu, Q., Schwarz, L. B., \& Uhan, N. (2012). The Impact of Group Purchasing Organizations on Healthcare-Product Supply Chains. Manufacturing \& Service Operations Management, 14(1), 7-23. Retrieved from https://pubsonline.informs.org/doi/10.1287/ msom.1110.0355

13. Inderst, R., \& Wey, C. (2007). Buyer power and supplier incentives. European Economic Review, 51(3), 647-667. https:// doi.org/10.1016/j.euroecorev.2006.02.002

14. Kauffman, R. J., \& Wang, B. (2002). Big together, buy together: On the efficacy of group-buying business models in Internet-based selling. Florida CRC Press. Retrieved from https://www.researchgate. net/publication/228688784 Bid_Together_Buy_Together_On_the_Efficacy_of_GroupBuying_Business_Models_in_Internet-Based_Selling
15. Marvel, H. P., \& Yang, H. (2008). Group purchasing, nonlinear tariffs, and oligopoly. International Journal of Industrial Organization, 26(5), 1090-1105. https://doi. org/10.1016/j.ijindorg.2007.10.002

16. Nollet, J., \& Beaulieu, M. (2005). Should an organization join a purchasing group? Supply Chain Management, 10(1), 11-17. Retrieved from https://www. emerald.com/insight/content/ doi/10.1108/13598540510578333/ full/html

17. Nollet, J., \& Beaulieu, M. (2003). The development of group purchasing: an empirical study in the healthcare sector. Journal of Purchasing and Supply Management, 9(1), 3-10. https://doi.org/10.1016/S09697012(02)00034-5

18. Nollet, J., Beaulieu, M., \& FabbeCostes, N. (2017). The impact of performance measurement on purchasing group dynamics: The Canadian experience. Journal of Purchasing \& Supply Management, 23(1), 17-27. https://doi. org/10.1016/j.pursup.2016.04.001

19. Picot, A., Ripperger, T., \& Wolff, B. (1996). The fading boundaries of the firm: the role of information and communication technology. Journal of Institutional and Theoretical Economics, 152(1), 65-79. Retrieved from https:// www.econbiz.de/Record/ the-fading-boundaries-of-thefirm-the-role-of-informationand-communication-technologypicot-arnold/10007406162

20. Polychronakis, Y., \& Syntetos, A. (2007). 'Soft' supplier management related issues: an empirical investigation. International Journal of Production Economics, 106(2), 431-449. https://doi. org/10.1016/j.ijpe.2006.07.008

21. Sandberg, E., \& Mena, C. (2015). Exploring strategic strengths and weakness of retail purchasing groups. The International Review of Retail, Distribution and Consumer Research, 25, 276-297. https://doi.org/10.1080/09593969. 2014.982679 
22. Sarkar, M. B., Echambadi, R., Cavusgil, S. T., \& Aulakh, P. S. (2001). The influence of complementarity, compatibility, and relationship capital on alliance performance. Journal of the Academy of Marketing Science, 29(4), 358-373. Retrieved from https://link.springer.com/article/10.1177/03079450094216

23. Schotanus, F. (2005). Unfair allocation of gains under equal price in cooperative purchasing (pp. 975-986). IPSERA

Conference Proceedings, Archamps, France. Retrieved from https://www.researchgate.net/ publication/254624297_Unfair_allocation_of_gains_under_equal_ price_in_cooperative_purchasing

24. Schotanus, F., \& Telgen, J. (2007). Developing a typology of organizational forms of cooperative purchasing. Journal of Purchasing \& Supply Management, 13(1), 53-68. https://doi. org/10.1016/j.pursup.2007.03.002

25. Schotanus, F., Telgen, J., \& de Boer, L. (2010). Critical success factors for managing purchasing groups. Journal of Purchasing \& Supply Management, 16(1), 51-60. https://doi.org/10.1016/j.pursup.2009.10.002

26. Tella, E., \& Virolainen, V. M. (2005). Motives behind purchasing consortia. International Journal of Production Economics, 93-94, 161-168. https://doi.org/10.1016/j. ijpe.2004.06.014

27. Vahid, T. K., Elham, G., Khosroshahi Mohsen, A., \& Mohammadreza, E. (2012). Working capital management and corporate performance: evidence from Iranian companies. Procedia - Social and Behavioral Sciences, 62, 1313-1318. https://doi. org/10.1016/j.sbspro.2012.09.225

28. Vining, A., \& Globerman, S. (1999). A conceptual framework for understanding the outsourcing decision. European Management Journal, 17(6), 645-654. https://doi.org/10.1016/ S0263-2373(99)00055-9

29. Williamson, O. E. (1991). Comparative economic organization: the analysis of discrete structural alternatives. Administrative Science Quarterly, 36(2), 269-296. https://doi. org/10.2307/2393356

30. Williamson, O. E. (2000). The new institutional economics: taking stock, looking ahead. Journal of Economic Literature, 38(3), 595-613. Retrieved from https://www.jstor.org/ stable $/ 2565421$ ?seq $=1$

31. Wooten, B. (2003). Cooperative purchasing in the 21st century. Inside Supply Management, 14(2), 4-7.
32. Yang, Ch., Cheng, H. K., Ding, C., \& Li, S. (2017). To join or not to join group purchasing organization: A vendor's decision. European Journal of Operational Research, 258(2), 581-589. https://doi.org/10.1016/j. ejor.2016.08.069

33. Zhou, M., Dan, B., Ma, S., \& Zhang, X. (2017). Supply chain coordination with information sharing: The informational advantage of GPOs. European Journal of Operational Research, 256, 785-802. Retrieved from https://www.researchgate.net/ publication/304454795_Supply_ Chain_Coordination_with_Information_Sharing_The_Informational_Advantage_of_GPOs

34. Zimon, D., \& Zimon, G. (2019a). The Impact of Implementation of Standardized Quality Management Systems on Management of Liabilities in Group Purchasing Organizations. Quality Innovation Prosperity, 23(1), 60-73. Retrieved from http://www.qip-journal.eu/index. $\mathrm{php/QIP/article/view/1210}$

35. Zimon, G., \& Zimon, D. (2019b). The impact of quality management systems on financial liquidity in companies in group purchasing organizations. WSEAS Transactions on Business and Economics, 16, 163-170. 